\title{
Assessing New Banana Genotypes for Relevant Traits: Implication for Variety Selection
}

\author{
Robooni Tumuhimbise ${ }^{1}$ (D), Alex Barekye ${ }^{2}$, David Talengera ${ }^{3}$, Kenneth Akankwasa ${ }^{4}$, \\ Kephas Nowakunda $^{*}{ }^{*}$, Moreen Asasira ${ }^{4}$, Deborah Karamura5, Eldad Karamura ${ }^{5}$ \\ ${ }^{1}$ Rwebitaba Zonal Agricultural Research and Development Institute, Fort Portal, Uganda \\ ${ }^{2}$ Kachwekano Zonal Agricultural Research and Development Institute, Kabale, Uganda \\ ${ }^{3}$ Faculty of Agriculture, Ndejje University, Kampala, Uganda \\ ${ }^{4}$ National Agricultural Research Laboratories (Kawanda), Kampala, Uganda \\ ${ }^{5}$ Bioversity International, Kampala, Uganda \\ Email: *nowakunda@gmail.com
}

How to cite this paper: Tumuhimbise, R., Barekye, A., Talengera, D., Akankwasa, K., Nowakunda, K., Asasira, M., Karamura, D. and Karamura, E. (2020) Assessing New Banana Genotypes for Relevant Traits: Implication for Variety Selection. Agricultural Sciences, 11, 1017-1032.

https://doi.org/10.4236/as.2020.1111066

Received: September 11, 2020

Accepted: November 13, 2020

Published: November 16, 2020

Copyright $\odot 2020$ by author(s) and Scientific Research Publishing Inc. This work is licensed under the Creative Commons Attribution International License (CC BY 4.0).

http://creativecommons.org/licenses/by/4.0/

\begin{abstract}
Understanding the performance of new crop genotypes for traits of relevance is important in selecting potential cultivars to satisfy end-users. The objective of this study was to determine the performance of new banana genotypes for bunch mass (BMS) and BMS-related traits, resistance to black Sigatoka and sensory attributes. Eight cooking banana genotypes consisting of six new hybrid genotypes selected from advanced breeding trials and two control cultivars were evaluated in a randomized complete block design for three crop cycles at three locations in Uganda. Genotype, location, crop cycle and their interaction effects were significantly different for most traits assessed. The overall top two genotypes ("9058K-2" and "8099K-16") combining high BMS, resistance to black Sigatoka and acceptable sensory attributes were identified. These genotypes are suggested as potential commercial cultivars for release to farmers in Uganda and/or other East African countries with similar environmental conditions to those where the genotypes were tested. It should be noted that high BMS/yield and resistance to diseases are not the only factors to consider when selecting banana genotypes that meet end-user needs. A combination of high BMS/yield, acceptable sensory attributes and resistance to diseases essentially influence the selection process of banana cultivars.
\end{abstract}

\section{Keywords}

Agronomic and Sensory Traits, Black Sigatoka, Cooking Banana, Resistance Screening, Selection, Musa spp. 


\section{Introduction}

Banana (Musa spp.), a perennial and vegetatively-propagated plant, is an important crop in the tropical and subtropical regions of the world [1]. It is a source of food and income for millions of smallholder farmers, especially in Asia, South and Central America, and sub-Saharan Africa (SSA) [2] [3]. Majority of the banana production in SSA is done on small plots and backyard gardens [3].

Every part of the banana plant is useful although the fruit is the most used plant part. The mature fruit of banana can be utilized in many forms, such as dessert when fully ripe, food when cooked and mashed or eaten directly after boiling or steaming [4] [5]. When cooked or steamed, banana, especially the cooking East African Highland Bananas (EAHBs) "Matooke", are characterized by a unique flat taste and aroma, golden yellow colour and a soft texture [6]. Fruits, especially those of beer type of bananas "Embire" also the EAHBs can be squeezed when fully ripe to produce a natural sweet juice "Eshande" which upon fermentation can be processed into wine and/or "Waragi"; a tradition drink enjoyed in most east African countries.

The highest per capita consumption of banana in the world is in the East African region, where one-third of the people depend on this crop as a staple food-the crop occupies between $20 \%$ and $30 \%$ of the acreage under cultivation [7]. Annual production of bananas in the region is worth US\$ 4.3 billion, accounting for about $5 \%$ of the region's gross domestic product [8]. The predominant type of bananas grown in East Africa is the EAHBs. These are a subgroup of triploid banana cultivars, with genome code AAA [9].

In Uganda, millions of people rely on banana for income and daily food, with approximately $75 \%$ of farmers cultivating the crop [10]. Banana occupies the third largest cultivated area amongst staple food crops in Uganda [1]. Despite the benefits of growing bananas in the country, the yield gap between the actual and potential is high. For example, over the last 30 years, banana yields have been declining with low yields of 5 to $10 \mathrm{t} / \mathrm{ha}$ /year compared to potential yield of $70 \mathrm{t} / \mathrm{ha}$ /year and bunch mass dropping from 60 to $10 \mathrm{~kg} / \mathrm{plant}$ or less [1] [11]. The number of years that banana plantations continue to be productive in some parts of Uganda, especially the central region, has been reduced to only five years compared to 50 years of plantation productivity in the past. The leading factors responsible for the decline in yield and productivity life are largely due to susceptibility of local cultivars to pests [11], especially banana weevils and nematodes; and diseases, particularly black Sigatoka [12] [13] [14].

Black Sigatoka, also known as black leaf streak disease, caused by the fungus Mycosphaerella fijiensis (Morelet), is the most serious disease threat to banana production worldwide, causing yield losses of up to 50\% [14] [15]. Heavy infestation of black Sigatoka to banana can lead to a considerable reduction in the photosynthetic leaf area of the plant [15]. Consequently, bunches and fruits of infected plants produce lower bunch yield in comparison to those of healthy banana plants. Severe Sigatoka disease infection has also been reported to cause a 
marked effect on banana ripening after harvest [16].

There are several potential technology-based interventions to address the problem of black Sigatoka disease [17] [18] [19], however, developing resistant cultivars is the most fundamental intervention. Resistant cultivars offer enormous spill over benefits for human health and positive environmental impacts [19] [20].

The National Agricultural Research Organization (NARO) of Uganda initiated a banana breeding program in the early-1990s, which has over the years developed hybrid genotypes, some of which have been officially released to farmers for production [21] [22]. Several other hybrid genotypes are under evaluation for eventual release to farmers. In this study, we present and discuss the results of six new hybrid banana genotypes, which were selected from advanced yield trials of NARO and evaluated together with two control cultivars for traits of relevance for three crop cycles at three locations in the major banana growing areas of Uganda. Adoption of new banana cultivars in Uganda has been reported to be largely dependent on a combination of sensory, yield and disease resistance traits [23]. The objective of this study therefore was to determine the performance of new banana genotypes for bunch mass (BMS) and BMS-related traits, resistance to black Sigatoka and food sensory attributes.

\section{Materials and Methods}

\subsection{Banana Germplasm}

Eight cooking banana entries consisting of six new genotypes from advanced banana breeding evaluation trials of NARO and two control cultivars (improved and landrace) from farmers' fields in Uganda were used for this study (Table 1). Selection of six new genotypes was based on their previous performance for bunch yield of over $10 \mathrm{~kg} / \mathrm{bunch}$ and resistance to black Sigatoka. The control

Table 1. Eight cooking banana genotypes used in the experiment.

\begin{tabular}{cccc}
\hline SN. & Genotype & Ploidy & Remark \\
\hline 1. & $10054 \mathrm{~K}-1$ & $3 \times$ & New genotype \\
2. & $10072 \mathrm{~K}-10$ & $3 \times$ & New genotype \\
3. & $6880 \mathrm{~K}-2$ & $3 \times$ & New genotype \\
4. & $8099 \mathrm{~K}-16$ & $3 \times$ & New genotype \\
5. & $9019 \mathrm{~K}-3$ & $3 \times$ & New genotype \\
6. & $9058 \mathrm{~K}-2$ & $3 \times$ & New genotype \\
7. & Kabana $6 \mathrm{H}$ & $3 \times$ & $\begin{array}{c}\text { Control improved cooking banana cultivar, } \\
\text { with resistance to black Sigatoka }[12] .\end{array}$ \\
8. & Mbwazirume & $3 \times$ & $\begin{array}{c}\text { Control landrace cooking banana cultivar, } \\
\text { with farmer preferred quality attributes } \\
\text { but susceptible to black Sigatoka [6]. }\end{array}$ \\
\hline
\end{tabular}


cultivars "Kabana $6 \mathrm{H}$ " and "Mbwazirume" were selected based on their predominance in cultivation as improved and landrace cultivars, respectively. In addition "Kabana $6 \mathrm{H}$ " is a black-Sigatoka-resistant improved cultivar [12] whereas "Mbwazirume" is a most farmer-preferred landrace cultivar due to its superior food quality attributes (good taste, aromatic, good mouth feel, golden yellow colour) but susceptible to black Sigatoka.

\subsection{Experimental Sites}

Experiments were conducted at three sites: Mbarara Zonal Agricultural Research and Development Institute, located in south western Uganda at $0^{\circ} 36^{\prime} 16^{\prime \prime S}$ and $3^{\circ} 38^{\prime} 54 " E, 1430$ meters above sea level (masl); National Agricultural Laboratories-Kawanda, located in central Uganda at $0^{\circ} 25^{\prime} 14^{\prime \prime} \mathrm{N}$ and $32^{\circ} 32^{\prime} 26^{\prime \prime} \mathrm{E}, 1300$ masl, and Nakabango Agricultural Research Station-Jinja, located in eastern Uganda at $0^{\circ} 26^{\prime} 20^{\prime \prime} \mathrm{N}$ and $33^{\circ} 12^{\prime} 11^{\prime \prime} \mathrm{E}, 1187$ masl. Mbarara received an average annual rainfall of $1214 \mathrm{~mm}$ during the experimental period, while Kawanda and Jinja received average annual rainfall of $1390 \mathrm{~mm}$ and $1400 \mathrm{~mm}$, respectively. Mbarara is characterized by low black Sigatoka disease pressure while Kawanda and Jinja are characterized by high black Sigatoka disease pressure. The experiments were conducted from September 2014 to November 2018.

\subsection{Experimental Design}

Experiments at each site were laid out in a randomized complete block design with four replications. Two-months old tissue culture plants of each genotype were planted in deep holes ( $0.4 \mathrm{~m}$ deep and $0.6 \mathrm{~m}$ wide) spaced at $3 \mathrm{~m} \times 3 \mathrm{~m}$. To ensure the spread of black Sigatoka inoculum "spore", experimental fields were established in the middle of existing banana plantations with blacks Sigatoka susceptible local banana cultivars. The blocks were further surrounded with black Sigatoka infected plants of "Mbwazirume" to act as spreaders. Five kilograms of kraal organic manure $(5 \mathrm{~kg})$ were applied to the planting holes at planting and the banana test materials provided regular good management practices [24].

\subsection{Data Collection}

Data were collected on the number of standing leaves (NSL), youngest leaf spotted (YLS) and index of non-spotted leaf (INSL) at plant flowering. The INSL is the proportion of standing leaves without the typical late stage symptoms of black leaf streak disease, i.e. a black spot with a necrotic centre [25]. INSL provides an estimation of available photosynthetic leaf area prior to fruit filling and is a measure of resistance to black Sigatoka [26]. Data at harvest were collected on bunch mass (BMS), total number of clusters (NCL) and fruits (NFT), and sensory attributes of cooked food of all the genotypes evaluated. The NSL was determined by direct counting of all standing leaves on a banana plant at flowering. YLS was determined by counting down from the top of the plant the leaf 
number of the first fully unfurled leaf with at least 10 discrete, mature, necrotic lesions or one large necrotic area with 10 light-coloured dry centres [26] and the INSL was calculated from NSL and YLS [26] as follows:

$$
\text { INSL }=\frac{(\text { YLS }-1) \times 100}{\text { NSL }}
$$

where:

INSL = Index of Non-Spotted Leaf,

YLS $=$ Youngest Leaf Spotted, and

NSL $=$ Number of Standing Leaves.

The BMS (kg/plant) was determined by weighing the harvested bunches individually using a digital weighing scale. The NCL and TNF were determined by direct counting of clusters and fruits on a bunch, respectively.

The assessment of genotypes for food sensory attributes was performed at the second ratoon crop using a total of 164 banana farmers across the sites. Before the exercise, farmers were first trained to carry out evaluations of food based on five sensory attributes of taste, aroma, mouth feel, color and overall acceptability, using a scale of 1 to 6 ; where $1=$ dislike extremely, $2=$ dislike, $3=$ like fairly, $4=$ like, 5 = like very much, $6=$ like extremely.

\subsection{Statistical Analysis}

The data collected were subjected to analysis of variance (ANOVA) using GenStat, version 14 [27]. Means were separated using the Least Significance Differences (LSD) at $\mathrm{P}<0.05$. To identify and select high yielding banana genotypes with resistance to black Sigatoka and combining good sensory attributes, all the genotypes were sorted and ranked based on their performance for each trait of the 10 traits assessed across sites and cycles using Microsoft Excel [28]. Individual trait ranks were added; and a genotype with the lowest overall rank of one or close to one was considered the best genotype. Ranking was conducted on a scale of 1 to 8 ; where; $1=$ Excellent and $8=$ Worst.

\section{Results}

\subsection{Performance of Genotypes in Response to Locations}

Genotypes and locations were significantly different for all the agronomic traits assessed (Table 2). Their second order interaction effects were similarly significantly different for all traits except for bunch mass (Table 2).

\subsubsection{Bunch Mass}

The highest mean performance for bunch mass across genotypes was recorded in Mbarara (28.0 kg/plant) and lowest in Kawanda (25.4 kg/plant) (Table 2). Genotype "8099K-16" produced highest bunch mass (31.4 kg/plant), followed closely by "9058K-2" (31.24 kg/plant) and "Kabana $6 \mathrm{H}$ " (30.4 kg/plant). The least mean bunch mass of $13.8 \mathrm{~kg} /$ plant was recorded by "10054K-1" (Table 2). 
Table 2. Mean performance of eight cooking banana genotypes for five traits evaluated at three locations across three crop cycles in Uganda from 2014 to 2018.

\begin{tabular}{|c|c|c|c|c|c|c|c|c|c|c|c|c|c|c|c|c|c|c|c|c|}
\hline \multirow{3}{*}{ Genotype } & \multicolumn{4}{|c|}{ Bunch Mass (Kg/plant) } & \multicolumn{4}{|c|}{ Number of Clusters } & \multicolumn{4}{|c|}{ Number of Fruits } & \multicolumn{4}{|c|}{$\begin{array}{c}\text { Number of } \\
\text { Standing Leaves }\end{array}$} & \multicolumn{4}{|c|}{$\begin{array}{c}\text { Index of } \\
\text { Non-Spotted Leaf }\end{array}$} \\
\hline & \multicolumn{4}{|c|}{ Location } & \multicolumn{4}{|c|}{ Location } & \multicolumn{4}{|c|}{ Location } & \multicolumn{4}{|c|}{ Location } & \multicolumn{4}{|c|}{ Location } \\
\hline & $\mathrm{JN}$ & KW & MB & Mean & $\mathrm{JN}$ & KW & MB & Mean & $\mathrm{JN}$ & KW & $\mathrm{MB}$ & Mean & $\mathrm{JN}$ & KW & MB & Mean & $\mathrm{JN}$ & KW & MB & Mean \\
\hline $10054 \mathrm{~K}-1$ & $14.1 \mathrm{a}$ & $12.1 \mathrm{a}$ & $15.5 \mathrm{a}$ & $13.8 \mathrm{a}$ & $5.6 \mathrm{a}$ & $5.7 \mathrm{a}$ & $7.6 \mathrm{a}$ & $6.3 \mathrm{a}$ & $62.8 \mathrm{a}$ & $70.6 \mathrm{a}$ & $85.7 \mathrm{a}$ & $73.0 \mathrm{a}$ & $9.6 \mathrm{a}$ & $7.8 \mathrm{a}$ & $10.8 \mathrm{a}$ & $9.4 \mathrm{a}$ & $82.7 \mathrm{a}$ & $75.6 \mathrm{a}$ & $94.4 \mathrm{a}$ & $84.2 \mathrm{a}$ \\
\hline $10072 \mathrm{~K}-10$ & $25.5 \mathrm{bd}$ & $23.2 \mathrm{~b}$ & $26.5 b$ & $24.8 \mathrm{~b}$ & $8.2 \mathrm{~b}$ & $8.4 \mathrm{~b}$ & $10.2 \mathrm{~b}$ & $9.0 \mathrm{bc}$ & $122.4 \mathrm{~b}$ & $135.4 \mathrm{~b}$ & $154.2 \mathrm{de}$ & $137.3 \mathrm{bc}$ & $10.3 \mathrm{ab}$ & $10.1 \mathrm{~b}$ & $10.5 \mathrm{a}$ & $10.3 b$ & $76.0 \mathrm{a}$ & $72.5 \mathrm{a}$ & $82.6 \mathrm{~b}$ & $77.1 \mathrm{ab}$ \\
\hline $6880 \mathrm{~K}-2$ & $26.5 b$ & $29.4 \mathrm{c}$ & $29.8 \mathrm{c}$ & $28.6 \mathrm{c}$ & $8.5 \mathrm{c}$ & $8.4 \mathrm{~b}$ & $10.2 \mathrm{~b}$ & $9.0 \mathrm{bc}$ & $119.6 \mathrm{~b}$ & $127.1 \mathrm{~b}$ & $120.7 \mathrm{~b}$ & $122.5 b$ & $10.9 \mathrm{~b}$ & $12.3 \mathrm{c}$ & $13.9 \mathrm{~d}$ & $12.4 \mathrm{c}$ & $78.9 a$ & 71.1a & $76.0 \mathrm{~b}$ & $75.3 \mathrm{~b}$ \\
\hline $8099 \mathrm{~K}-16$ & $31.5 \mathrm{c}$ & $29.8 \mathrm{c}$ & $32.9 \mathrm{c}$ & $31.4 \mathrm{~d}$ & $8.6 \mathrm{c}$ & $8.9 \mathrm{~d}$ & $10.2 \mathrm{~b}$ & $9.2 \mathrm{bd}$ & $125.7 \mathrm{bc}$ & $132.5 \mathrm{~b}$ & $137.3 \mathrm{~cd}$ & $131.8 \mathrm{~b}$ & $11.0 \mathrm{bc}$ & $12.9 \mathrm{c}$ & $13.3 \mathrm{~d}$ & $12.4 \mathrm{c}$ & $78.5 \mathrm{a}$ & $71.2 \mathrm{a}$ & $75.8 \mathrm{bc}$ & $75.1 \mathrm{~b}$ \\
\hline $9019 \mathrm{~K}-3$ & $29.0 \mathrm{c}$ & $26.4 \mathrm{~d}$ & $29.4 \mathrm{c}$ & $28.3 c$ & $8.2 \mathrm{~b}$ & $8.2 \mathrm{~b}$ & $9.8 \mathrm{~b}$ & $8.7 c$ & $114.8 \mathrm{~b}$ & $130.0 \mathrm{~b}$ & $128.4 \mathrm{bc}$ & $124.4 \mathrm{~b}$ & $10.9 \mathrm{~b}$ & $12.1 \mathrm{c}$ & $13.7 \mathrm{~d}$ & $12.2 \mathrm{c}$ & $78.7 \mathrm{a}$ & $74.7 \mathrm{a}$ & $74.4 \mathrm{c}$ & $75.9 \mathrm{~b}$ \\
\hline $9058 \mathrm{~K}-2$ & $32.0 \mathrm{c}$ & $30.5 \mathrm{c}$ & $32.2 \mathrm{c}$ & $31.2 \mathrm{~d}$ & $8.9 \mathrm{~d}$ & $9.0 \mathrm{~d}$ & $10.3 \mathrm{~b}$ & $9.4 \mathrm{~d}$ & $146.9 \mathrm{~d}$ & $153.3 \mathrm{c}$ & $150.1 \mathrm{de}$ & $150.1 \mathrm{c}$ & $11.8 \mathrm{bcd}$ & $11.8 \mathrm{c}$ & $15.9 \mathrm{e}$ & $13.2 \mathrm{~d}$ & $78.3 \mathrm{a}$ & $79.7 \mathrm{~b}$ & $71.4 \mathrm{c}$ & $76.5 \mathrm{ab}$ \\
\hline Kabana $6 \mathrm{H}$ & $30.8 \mathrm{c}$ & $28.1 \mathrm{~cd}$ & $32.2 \mathrm{c}$ & $30.4 \mathrm{~d}$ & $8.4 c$ & $8.6 \mathrm{~b}$ & $10.0 \mathrm{~b}$ & $9.0 \mathrm{bc}$ & $105.2 \mathrm{~b}$ & $128.7 \mathrm{~b}$ & $141.7 \mathrm{de}$ & $125.2 b$ & $11.1 \mathrm{bc}$ & $12.5 \mathrm{c}$ & $13.4 \mathrm{~d}$ & $12.3 \mathrm{~b}$ & 76.a & $73.5 \mathrm{a}$ & $72.0 \mathrm{c}$ & $74.0 \mathrm{~b}$ \\
\hline Mbwazirume & $23.2 \mathrm{~d}$ & $24.1 \mathrm{~b}$ & $25.5 b$ & $24.3 \mathrm{~b}$ & $7.6 \mathrm{~b}$ & $7.6 \mathrm{e}$ & $9.6 \mathrm{~b}$ & $8.3 \mathrm{e}$ & $115.9 \mathrm{~b}$ & $123.7 \mathrm{~b}$ & $129.7 \mathrm{bc}$ & $123.1 \mathrm{~b}$ & $8.5 \mathrm{e}$ & $8.3 \mathrm{a}$ & $12.1 \mathrm{c}$ & $9.6 \mathrm{a}$ & $54 . \mathrm{b}$ & $50.4 \mathrm{c}$ & $57.9 \mathrm{~d}$ & $54.2 \mathrm{c}$ \\
\hline MEAN & $26.6 \mathrm{~A}$ & $25.4 \mathrm{~B}$ & $28.0 \mathrm{C}$ & 26.7 & $8.0 \mathrm{~A}$ & $8.1 \mathrm{~A}$ & $9.7 \mathrm{~B}$ & 8.6 & $114.2 \mathrm{~A}$ & $125.2 \mathrm{~B}$ & $131.0 \mathrm{C}$ & 123.4 & $10.5 \mathrm{~A}$ & $11.0 \mathrm{~B}$ & $13.0 \mathrm{C}$ & 11.5 & $75.5 \mathrm{~A}$ & $71.1 \mathrm{~B}$ & $75.5 \mathrm{~A}$ & 74.0 \\
\hline \multicolumn{21}{|c|}{ F-Probability } \\
\hline \multicolumn{4}{|c|}{ Genotype (G) } & $<0.001$ & & & & $<0.001$ & & & & $<0.001$ & & & & $<0.001$ & & & & $<0.001$ \\
\hline \multicolumn{4}{|c|}{ Location (L) } & 0.010 & & & & $<0.001$ & & & & $<0.001$ & & & & $<0.001$ & & & & $<0.001$ \\
\hline \multicolumn{4}{|c|}{$\mathrm{G} \times \mathrm{L}$ Interaction } & NS & & & & 0.025 & & & & $<0.001$ & & & & $<0.001$ & & & & $<0.001$ \\
\hline \multicolumn{21}{|c|}{ LSD (0.05) } \\
\hline \multicolumn{4}{|c|}{ Genotype Mean } & 1.57 & & & & 0.31 & & & & 7.87 & & & & 0.52 & & & & 2.79 \\
\hline \multicolumn{4}{|c|}{$\mathrm{G} \times$ L Interaction Mean } & NS & & & & 0.80 & & & & 20.1 & & & & 1.32 & & & & 7.12 \\
\hline
\end{tabular}

Means with the same small letter within the same column do not differ significantly according to Fisher's test of least significant differences $(\mathrm{P}<0.05)$. Means with the same Capital letter within the same row do not differ significantly according to Fisher's test of least significant differences $(\mathrm{P}<0.05)$. JN $=$ Jinja, KW = Kawanda, MB = Mbarara. LSD (0.05) = Least Significant Difference at 5\%.

All genotypes had least performance for bunch mass in Kawanda except for "6880K-2" and "Mbwazirume" whose least performance was recorded in Jinja.

\subsubsection{Total Number of Clusters}

The highest mean performance for number of clusters across genotypes was recorded in Mbarara (9.7), while Jinja and Kawanda produced almost the same number of clusters of 8.0 and 8.1, respectively (Table 2). Genotype "9058K-2" produced highest number of clusters (9.4) trailed by " $8099 \mathrm{~K}-16$ " with 9.2 clusters, and "10072K-10", "6880K-2" and "Kabana 6H", all with 9.0 clusters. Genotypes "9019K-3" and "Mbwazirume" had the same trend of performance for the number of clusters in Jinja and Kawanda while "6880K-2" performed slightly better in Jinja than Kawanda although their performance for the trait was not significantly different. For the rest of the genotypes, performance for number of clusters was highest in Mbarara, followed by Kawanda and least in Jinja. 


\subsubsection{Total Number of Fruits}

The highest performance of the genotypes for total number of fruits was observed in Mbarara (131) and the least in Jinja (114.2) (Table 2). Genotype "9058K-2" recorded highest number of fruits (150.1) trailed by "10072K-10" (137.3) and " $8099 \mathrm{~K}-16$ ", while "10054K-1" recorded the least number for the trait. Genotypes “10054K-1", “10072K-10”, “8099K-16”, "Kabana 6H”, and “Mbwazirume" performed highly for the total number of fruits in Mbarara, followed by Kawanda and least in Jinja whereas genotypes "6880K-2", "9019K-3", and "9058K-2" performed highly for the trait in Kawanda followed by Mbarara and least similarly in Jinja.

\subsubsection{Number of Standing Leaves}

Performance of the genotypes for number of standing leaves was highest in Mbarara followed by Kawanda and least in Jinja (Table 2). Genotype "9058K-2" recorded highest number of standing leaves followed closely by "6880K-2", "8099K-16", "Kabana 6H" and "9019K-3". Genotypes "10054K-1" and "Mbwazirume" had the least number of standing leaves. Genotypes "10054K-1", "10072K-10", "Kabana6H" and "Mbwazirume" recorded the lowest number of standing leaves in Kawanda while genotypes "6880K-2", “8099K-16" and "9019K-3" recorded the lowest number for the trait in Jinja. Only "9058K-2" recorded the lowest number of leaves in Mbarara.

\subsubsection{Index of Non-Spotted Leaf}

Jinja and Mbarara recorded an equal and highest index of non-spotted leaf across genotypes (75.5\%), while Kawanda recorded the lowest of $71.1 \%$ (Table 2). All hybrid genotypes were above $70 \%$ of index of non-spotted leaf and are thus, resistant to black Sigatoka. Genotypes "10054K-1", "10072K-10”, “6880K-2”, "8099K-16" and "Mbwazirume" had the least index of non-spotted leaf in Kawanda while "9019K-3", "9058K-2" and "Kabana 6H" had the least for the trait in Mbarara. Highest index of non-spotted leaf in Mbarara was recorded by "10054K-1", "10072K-10" and "Mbwazirume". The highest in Jinja was recorded by "6880K-2", "8099K-16”, “9019K-3" and Kabana 6H.

\subsection{Performance Genotypes in Response to Crop Cycles}

Genotypes were significantly different for all the agronomic traits assessed while plant cycles were significantly different for only bunch mass, number of clusters and fruits (Table 3 ). Genotypes $\times$ crop cycle interaction effects were significantly different for all the traits (Table 3 ).

\subsubsection{Bunch Mass}

The bunch mass of all genotypes except "Mbwazirume" increased gradually from plant crop to second ratoon crop (Table 3). "Mbwazirume" attained the highest bunch mass $(25.6 \mathrm{~kg} / \mathrm{plant})$ at $\mathrm{t}$ plant crop, which reduced at first and second ratoon crops to $23.8 \mathrm{~kg} / \mathrm{plant}$. Averaged across genotypes, the highest 
Table 3. Mean performance of eight cooking banana genotypes for five traits evaluated across three locations for three crop cycles in Uganda from 2014 to 2018.

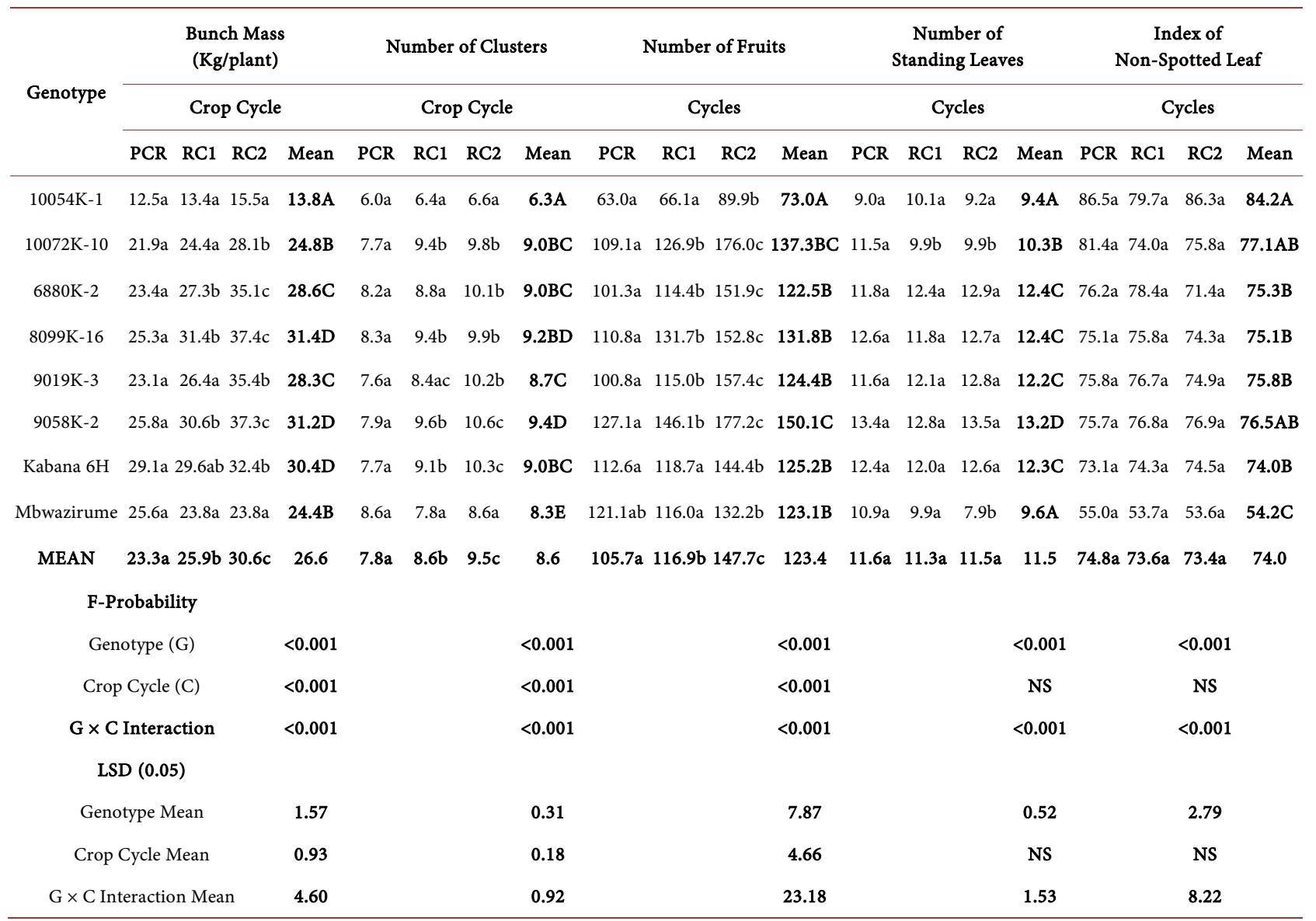

Means with the same small letter within the same row do not differ significantly according to Fisher's test of least significant differences $(\mathrm{P}<0.05)$. Means with the same capital letter within the same column do not differ significantly according to Fisher's test of least significant differences $(\mathrm{P}<0.05)$. PCR $=$ Plant Crop, RC1 = First Ratoon Crop, RC2 = Second Ratoon Crop; LSD (0.05) = Least Significant Difference at 5\%.

bunch mass was obtained at the second ratoon crop (36.6 kg/plant) and the least bunch mass obtained at plant crop stage $(23.3 \mathrm{~kg} / \mathrm{plant})$.

\subsubsection{Total Number of Clusters}

The total number of clusters for all genotypes except "Mbwazirume" increased gradually from plant crop to second ratoon crop (Table 3). "Mbwazirume", attained the highest number of clusters (8.6) at plant and second ratoon crops and the least number of clusters at the first ratoon (7.8). Averaged across genotypes, the highest number of clusters was observed at the second ratoon crop (9.5) and the least observed at plant crop (7.8).

\subsubsection{Total Number of Fruits}

The genotypes performance for total number of fruits took the same trend, increasing from plant crop to the second ratoon crop cycles except for "Mbwazirume" (Table 3). Mbwazirume had the highest number of fruits at the second ratoon crop cycle (132.2), followed by plant crop (121.1) and the least at first ra- 
toon crop cycle (116). Averaged across genotypes, the highest number of fruits was observed at second ratoon crop (147.7) and the leased observed at plant crop cycle (105.7).

\subsubsection{Number of Standing Leaves}

Averaged across genotypes, the numbers of functional leaves at plant and ratoon crop cycles were not significantly different (Table 3 ). However, the highest mean performance for the trait was observed at the plant crop phase. With the exception of "Mbwazirume" and "10072K-10" that attained the highest number of functional leaves at the plant crop phase, the rest of the genotypes produced the highest number of functional leaves at the second ratoon crop phase.

\subsubsection{Index of Non-Spotted Leaf}

Averaged across genotypes, the Indices of non-spotted leaf at plant and ratoon crop cycles were not significantly different (Table 3). Nevertheless, the highest mean performances for these traits were observed at plant crop. Genotypes "10054K-1", "10072K-10" and Mbwazirume attained highest index of non-spotted leaf at plant crop while "6880K-2", "8099K-16" and "9019K-3" attained highest values for the trait at first ratoon crop. "Kabana $6 \mathrm{H}$ " and $9058 \mathrm{~K}-2$ attained the highest index of non-spotted leaf at the second ratoon crop. The index of non-spotted leaf values of "Mbwazirume" reduced gradually from the plant crop cycle to the second ratoon crop cycle.

\subsection{Performance of Genotypes for Sensory Attributes}

Banana genotypes differed significantly for all the sensory attributes evaluated (Table 4). For food taste, all genotypes had a score above 5.0 and the most superior genotypes for the trait were "8099K-16", "Mbwazirume" and "9058K-2". For food aroma and mouth feel, the most superior genotype was "Mbwazirume", which was trailed closely by " $8099 \mathrm{~K}-16$ " and "9058K-2". For food colour and overall acceptability, " $8099 \mathrm{~K}-16$ " performed highly, followed closely by "Mbwazirume" that was also followed closely by " $9058 \mathrm{~K}-2$ ".

\subsection{Overall Performance of the Genotypes for All the Traits Assessed}

To identify and select high yielding banana genotypes with resistance to black Sigatoka and combining good sensory attributes, genotypes were ranked for performance for each of the traits assessed (Tables 2-4). Top performers for a combination of the desired traits were identified. Accordingly, genotype "9058K-2" was ranked the most superior (Table 5 ). This was followed closely by " $8099 \mathrm{~K}-16$ ". There was not a single genotype that was superior in all the traits assessed. For instance, the best genotype for bunch mass was " $8099 \mathrm{~K}-16$ " while the best for total number of clusters was "9058K-2". For the total number of fruits, the best genotype was similarly " $9058 \mathrm{~K}-2$ ", while the best for number of standing leaves was "6880K-2". 
Table 4. Mean performance of six new cooking banana genotypes, one local control cultivar "Mbwazirume" and one hybrid control "Kabana $6 \mathrm{H}$ " for fruit sensory attributes evaluated at the second ratoon crop across three sites in Uganda in 2018.

\begin{tabular}{cccccc}
\hline \multirow{2}{*}{ Genotype } & \multicolumn{5}{c}{ Fruit sensory attributes (Hedonic scale: 1 - 6) } \\
\cline { 2 - 6 } & Taste & Aroma & Mouth Feel & Colour & Overall Acceptability \\
\hline $10054 \mathrm{~K}-1$ & $5.03 \mathrm{a}$ & $4.69 \mathrm{a}$ & $4.37 \mathrm{a}$ & $4.75 \mathrm{a}$ & $4.90 \mathrm{a}$ \\
$10072 \mathrm{~K}-10$ & $5.40 \mathrm{~b}$ & $4.47 \mathrm{~b}$ & $4.76 \mathrm{~b}$ & $5.15 \mathrm{~b}$ & $4.95 \mathrm{a}$ \\
$6880 \mathrm{~K}-2$ & $5.50 \mathrm{c}$ & $5.28 \mathrm{c}$ & $5.35 \mathrm{c}$ & $5.18 \mathrm{~b}$ & $5.33 \mathrm{~b}$ \\
$9019 \mathrm{~K}-3$ & $5.28 \mathrm{~d}$ & $4.69 \mathrm{a}$ & $5.22 \mathrm{~d}$ & $4.72 \mathrm{c}$ & $4.87 \mathrm{a}$ \\
$9058 \mathrm{~K}-2$ & $5.69 \mathrm{e}$ & $5.45 \mathrm{~d}$ & $5.64 \mathrm{e}$ & $5.75 \mathrm{~d}$ & $5.41 \mathrm{~b}$ \\
$8099 \mathrm{~K}-16$ & $5.85 \mathrm{f}$ & $5.59 \mathrm{de}$ & $5.78 \mathrm{f}$ & $5.93 \mathrm{e}$ & $5.79 \mathrm{c}$ \\
Kabana 6H & $5.20 \mathrm{~g}$ & $4.88 \mathrm{f}$ & $4.53 \mathrm{~g}$ & $4.29 \mathrm{f}$ & $4.40 \mathrm{~d}$ \\
Mbwazirume & $5.73 \mathrm{~h}$ & $5.70 \mathrm{e}$ & $5.79 \mathrm{f}$ & $5.92 \mathrm{e}$ & $5.78 \mathrm{c}$ \\
Mean & 5.46 & 5.09 & 5.18 & 5.21 & 5.18 \\
F-Probability & $<0.001$ & $<0.001$ & $<0.001$ & $<0.001$ & $<0.001$ \\
LSD (0.05) & $\mathbf{0 . 0 4}$ & $\mathbf{0 . 1 4}$ & $\mathbf{0 . 0 4}$ & $\mathbf{0 . 0 9}$ & $\mathbf{0 . 3 6}$ \\
\hline
\end{tabular}

Means with the same letter within the same column do not differ significantly according to Fisher's test of least significant differences $(\mathrm{P}<0.05)$. Hedonic scale of 1 to 6 , where: $1=$ dislike extremely, $2=$ dislike, $3=$ like fairly, 4 = like, 5 = like very much, $6=$ like extremely. LSD (0.05) = Least Significant Difference at $5 \%$.

Table 5. Eight cooking banana genotypes ranked by superiority of their traits (Tables 2-4) evaluated across three locations and crop cycles.

\begin{tabular}{ccccccccccccccc}
\hline & \multicolumn{8}{c}{ Ranking of banana genotypes based on superiority of their traits } \\
\cline { 2 - 10 } Genotype & BMS & NCL & NFT & NSL & INSL & TST & AMA & MF & CL & OA & Mean $\begin{array}{c}\text { Overall } \\
\text { Rank }\end{array}$ \\
\hline $10054 \mathrm{~K}-1$ & 8 & 8 & 6 & 8 & 1 & 8 & 6 & 8 & 6 & 6 & 6.5 & $8^{\text {th }}$ \\
$10072 \mathrm{~K}-10$ & 6 & 3 & 1 & 6 & 2 & 5 & 8 & 6 & 5 & 5 & 4.7 & $5^{\text {th }}$ \\
$6880 \mathrm{~K}-2$ & 4 & 3 & 3 & 2 & 5 & 4 & 4 & 4 & 4 & 4 & 3.7 & $3^{\text {rd }}$ \\
$8099 \mathrm{~K}-16$ & 1 & 2 & 8 & 2 & 6 & 1 & 2 & 2 & 1 & 1 & 2.6 & $2^{\text {nd }}$ \\
$9019 \mathrm{~K}-3$ & 5 & 6 & 5 & 5 & 4 & 6 & 6 & 5 & 7 & 7 & 5.6 & $6^{\text {th }}$ \\
$9058 \mathrm{~K}-2$ & 2 & 1 & 2 & 1 & 3 & 3 & 3 & 3 & 3 & 3 & 2.4 & $1^{\text {st }}$ \\
Kabana $6 \mathrm{H}$ & 3 & 3 & 7 & 4 & 7 & 7 & 5 & 7 & 8 & 8 & 5.9 & $7^{\text {th }}$ \\
Mbwazirume & 7 & 7 & 4 & 7 & 8 & 2 & 1 & 1 & 2 & 2 & 4.1 & $4^{\text {th }}$ \\
\hline
\end{tabular}

BMS $=$ bunch mass $(\mathrm{Kg} /$ plant $), \mathrm{NCL}=$ number of clusters, $\mathrm{NFT}=$ total number of fruits, $\mathrm{NFL}=$ number of standing leaves, INSL $=$ index of non-spotted leaf $(\%), \mathrm{TST}=$ taste, $\mathrm{AMA}=$ aroma, $\mathrm{MF}=$ mouth feel, $\mathrm{CL}=$ color, $\mathrm{OA}=$ overall acceptability.

\section{Discussion}

Understanding the performance of new cropgenotypes for traits of relevance is important in cultivar selection to satisfy end-users. This ultimately facilitates faster adoption of new cultivars when right cultivars are selected. The objective 
of this study was to determine the performance of new hybrid cooking banana genotypes for agronomic, sensory and black Sigatoka resistance traits to inform their selection process. To meet the stated objective, we evaluated eight cooking banana genotypes for bunch mass (BMS) and BMS-related traits, resistance to black Sigatoka and sensory attributes at three diverse locations for three crop cycles in Uganda.

Genotypes, locations and crop cycles and their two-way interaction effects were significantly different for most traits. Significant genotypic effects for the traits assessed revealed that the genotypes evaluated were significantly different and that phenotypic selection would be possible among them. Significant location effects on the other hand revealed that the locations from where the experiments were conducted were different from each other and therefore affected the performance of genotypes for traits evaluated. Certainly, the three sites (Mbarara, Jinja and Kawanda) during the experimental period registered different amounts of rain fall received. Mbarara received a total annual rainfall of 1214 $\mathrm{mm}$ while Kawanda and Jinja received total annual rains of $1390 \mathrm{~mm}$ and 1400 $\mathrm{mm}$, respectively. Besides, the sites differ by altitude and pressure for black $\mathrm{Si}$ gatoka disease. Of the three sites, Mbarara is at the highest altitude characterized by low pressure for black Sigatoka disease due to cooler environments. The three sites are indeed found in three distinct agro-ecological zones that receive different amounts of rain and temperatures and many other conditions [29]. Significant crop cycle effects for BMS, NCL and NFT revealed differences in crop cycles for these traits.

Plant-crop cycle in banana is usually associated with smaller bunches [30] as the initial mother plants are not yet acclimatized to the environmental conditions. With the progression of the cycles (first ratoon crop and subsequently second ratoon crop), bunches grow bigger because the ratoon plants are already acclimatized to the environmental conditions. The implication thereof is that, selection for BMS and its related traits should be appropriately performed on ratoon plants. There were no significant crop cycle effects on NSL and INSL, implying that the crop cycles were not any different for these traits, thus their selection can be conducted at any crop cycle of banana growth and development without losing any valuable information. It may also be important to note that NSL and resistance to black sigatoka are high heritable traits.

Significant genotype $\times$ location interaction effects for the traits assessed revealed that some of the genotypes had specific adaptation to one or more of the locations, while the significant genotype $\times$ crop cycle interaction effects for BMS and other traits were indicative of differences in patterns of yield performance among genotypes as previously reported [19].

Compared to other sites, Mbarara recorded the best performance for all the agronomic traits. This was due to favourable conditions and low pressure for black Sigatoka. Higher altitude areas in Uganda such as those in Mbarara are characterized by low pressure for black Sigatoka disease due to cooler tempera- 
tures [31]. Besides, the hybrids that were studied are derivatives of the local East African highland banana cultivars that are endemic to East Africa and highly adapted to high altitude areas of $\geq 1400$ masl in the East African region.

Performance of the genotypes for BMS and BMS-related traits (NCL and NFT) was generally lowest when bananas were harvested at plant crop cycle and highest when harvested at ratoon crop cycles, a trend that in part reflects the dynamics in banana growth and development [30]. Banana established from suckers or tissue culture plants grow through phases: the vegetative phase characterized by rapid growth of pseudostem and foliage; the flowering phase characterized by rapid shooting out of inflorescence from the heart of the pseudostem; and the fruiting phase, where the ovaries contained in the first (female) flowers grow rapidly, developing parthenocarpically into clusters of fruits, called hands. The numbers of fruits and clusters are cultivar-dependent.

At every phase of banana growth and development, dry mass production and partitioning between plant organs occur, although the rate differs during the growth stages of the plant and is also cultivar-dependent. During the growth of the plant crop, new suckers (ratoons) that would later develop into new mother plants emerge. The ratoon suckers from the initial mother plant are acclimatized to environmental conditions, and therefore produce much higher yields than the plant crop. This occurs usually in the absence of pests and diseases which would otherwise reduce yields of the sucker-plants (ratoon crop). Because the hybrid genotypes were resistant to black Sigatoka, they produced progressive yields from pant crop to ratoon crops (first and second). Mbwazirume a local cultivar susceptible to black Sigatoka, however, had reduced performance for BMS and other traits from the pant crop to ratoon crop. Resistance of hybrids to black $\mathrm{Si}$ gatoka was shown by the INSL of over 70\% compared to that of a susceptible cultivar "Mbwazirume" of less than 55\%. Carlier et al. [26] and Orjeda [32] revealed that bananas require more than $70 \%$ of active leaf foliage at flowering for proper development of the banana fruit. Resistance to black Sigatoka of over $70 \%$ of INSL is one of the key banana breeding targets of most banana breeding programmes in Africa. Severe infestation of bananas with black Sigatoka, can lead to a considerable reduction in the photosynthetic leaf area of the plant. Consequently, bunches and fruits of infected plants produce lower bunch weight in comparison to those of healthy banana plants [14] [15]. Vuylsteke et al. [33] revealed that resistance to black Sigatoka results from the interaction between a major recessive gene and two modifiers with additive effects.

The sensory attributes (taste, aroma, soft mouth feel, and colour) of "9058K-2" and " $8099 \mathrm{~K}-16$ " were consistently ranked high and closest to those of "Mbwazirume". "Mbwazirume" is one of the most consumer-preferred landrace cooking banana cultivars due to high quality attributes of its cooked food. It dominates the banana markets in Uganda and is therefore highly marketable. Adoption rates of improved banana cultivars are often low regardless of their economic importance in terms of higher yield and resistance to diseases [3]. Reasons given 
by farmers for low uptake include inferior taste, poor marketability compared to local cultivars, and risks associated with growing new cultivars [34]. Farmers indicate preference for local cultivars because of their superior sensory attributes (good taste, aromatic, good mouth feel, golden yellow colour), even if new cultivars have better agronomic traits and better response to biotic and abiotic stresses [3] [23]. It is therefore important that new banana cultivars in addition to high yield and resistance to pests and diseases should possess good sensory attributes to meet farmer needs and preferences for higher adoption. In the present study we selected and recommended two banana hybrid genotypes "9058K-2" and "8099K-16" because of their high BMS, resistance to black Sigatoka and good sensory attributes.

\section{Conclusion}

Banana genotypes evaluated in this study showed high degree of variation for all the traits assessed, implying high potential for selection among them. Significant differences among crop cycles for BMS, NCL and NFT, with higher mean performance for these traits observed at the second ratoon crop revealed that the selection for BMS and BMS-related traits can be perfectly done at the second ratoon crop for optimal results. Non-significant crop cycle effects for NSL and INSL showed that selection for these traits can be done at any crop cycle of banana without losing any valuable information. The top two banana genotypes that combined high BMS, resistance to black Sigatoka and acceptable sensory attributes were "9058K-2" and "8099K-16" (Table 2). These two genotypes are recommended as potential commercial cultivars in Uganda and/or other East African countries with similar environmental conditions to those where the genotypes were tested.

\section{Acknowledgements}

The authors thank Bioversity International and Government of Uganda for funding the study. They also thank the technicians, farmers and everyone who contributed to the study, especially in data collection and provision of necessary information or otherwise.

\section{Conflicts of Interest}

The authors declare no conflict of interest.

\section{References}

[1] FAOSTAT (2020). http://www.fao.org/faostat/en/\#data/QC/visualize

[2] Lorenzen, J., Tenkouano, A., Bandyopadhyay, R., Vroh, B., Coyne, D. and Tripathi, L. (2010) Overview of Banana and Plantain (Musa spp.) Improvement in Africa: Past and Future. Proceedings of International Conference on Banana and Plantain in Africa. Acta Horticulturae, 879, 595-604.

https://doi.org/10.17660/ActaHortic.2010.879.66 
[3] Marimo, P., Karamura, D., Tumuhimbise, R., Shimwela, M.M., Van den Bergh, I., Batte, M., Massawe, C.R.S., Okurut, A.W., Mbongo, D.B. and Crichton, R. (2019) Post-Harvest Use of Banana in Uganda and Tanzania: Product Characteristics and Cultivar Preferences of Male and Female Farmers. Lima (Peru). International Potato Center. RTB Working Paper, 3, 47 p.

[4] Marimo, P., Caron, C., Van den Bergh, I., Crichton, R., Weltzien, E., Ortiz, R. and Tumuhimbise, R. (2020) Gender and Trait Preferences for Banana Cultivation and Use in Sub-Saharan Africa: A Literature Review 1. Economic Botany, 74, 226-241. https://doi.org/10.1007/s12231-020-09496-y

[5] Nowakunda, K., Khakasa, E. and Matovu, M. (2019) Sample Preparation and Texture Analysis of Matooke. Biophysical Characterization of Quality Characteristics. RTB Foods Standard Operating Procedures. https://rtbfoods.cirad.fr

[6] Akankwasa, K., Marimo, P., Tumuhimbise, R., Asasira, M., Khakasa, E., Mpirirwe, I., Kleih, U., Forsythe, L., Fliedel, G., Dufour, D. and Nowakunda, K. (2020) The East African Highland Cooking Bananas "Matooke" Preferences of Farmers and Traders: Implications for Variety Development. International Journal of Food Science and Technolog. https://doi.org/10.1111/ijfs.14813

[7] Karamura, D., Karamura, E. and Tinzaara, W. (2012) Banana Cultivar Names, Synonyms and Their Usage in Eastern Africa. Kampala: Bioversity International, 1, $1-108$.

[8] EAC (2012) East African Community, Facts and figures. EAC Secretariat Arusha, Tanzania.

[9] Kitavi, M.T., Downing, J., Lorenzen, J., Karamura, D., Onyango, M., Nyine, M., Ferguson, M. and Spillane, C. (2016) The Triploid East African Highland Banana (EAHB) Gene Pool Is Genetically Uniform Arising from a Single Ancestral Clone that Underwent Population Expansion by Vegetative Propagation. Theoretical and Applied Genetics, 129, 547-561. https://doi.org/10.1007/s00122-015-2647-1

[10] Ochola, D., Jogo, W., Ocimati, W., Rietveld, A., Tinzaara, W., Karamura, D.A. and Karamura, E.B. (2013) Farmers' Awareness and Perceived Benefits of Agro-Ecological Intensification Practices in Banana Systems in Uganda. African Journal of Biotechnology, 12, 4603-4613. https://doi.org/10.5897/AJB12.2868

[11] Twesigye, C.K., Ssekatawa, K., Kiggundu, A., Tushemereirwe, W., Matovu, E. and Karamura, E. (2018) Corm Damage Caused by Banana Weevils Cosmopolites sordidus (Germar) Collected from Different Banana Growing Regions in Uganda. Agriculture and Food Security, 7, 73. https://doi.org/10.1186/s40066-018-0224-y

[12] Nowakunda, K., Barekye, A., Ssali, R.T., Namaganda, J., Tushemereirwe, W.K., Nabulya, G., Erima, R., Akankwasa, K. and Hilman, E. (2015) "Kiwangaazi" (syn "KABANA 6H”) Black Sigatoka Nematode and Banana Weevil Tolerant "Matooke" Hybrid Banana Released in Uganda. HortScience, 50, 621-623.

https://doi.org/10.21273/HORTSCI.50.4.621

[13] Tumuhimbise, R., Buregyeya, H., Barekye, A., SSali, T.R., Talengera, D., Kubiriba, J., Muhangi, S., Namagembe, B., Namanya, P., Arinaitwe, G., Tushemereirwe, W.K., Karamura, D. and Karamura, E. (2016) Selection of Cooking Banana Genotypes for Yield and Black Sigatoka Resistance in Different Locations in Uganda. Journal of Plant Breeding and Crop Science, 8, 60-71.

[14] Alakonya, A.E., Kimunye, J., Mahuku, G., Amah, D., Uwimana, B., Brown, A. and Swennen, R. (2018) Progress in Understanding Pseudocercospora Banana Pathogens and the Development of Resistant Musa germplasm. Plant Pathology, 67, 759-770. https://doi.org/10.1111/ppa.12824 
[15] Arzanlou, M., Abeln, E.C.A., Kema, G.H.J., Waalwijk, C., Carlier, J., de Vries, I., Guzmán, M. and Crous, P.W. (2007) Molecular Diagnostics for the Sigatoka Disease Complex of Banana. Phytopathology, 97, 1112-1118. https://doi.org/10.1094/PHYTO-97-9-1112

[16] Castelan, F., Saraiva, L.A., Lange, F., De Lapeyre, De Bellaire, L., Cordenunsi, B.R. and Chillet, M. (2012) Effects of Black Leaf Streak Disease and Sigatoka Disease on Fruit Quality and Maturation Process of Bananas Produced in the Subtropical Conditions of Southern Brazil. Crop Protection, 35, 127-131.

https://doi.org/10.1016/j.cropro.2011.08.002

[17] Perez-Vicente, L. (2012) Technical Manual: A Holistic Integrated Management Approach to Control Black Sigatoka Disease of Banana Caused by Mycosphaerella fijiensis. Food and Agriculture Organization of the United Nations, Sub Regional Office for the Caribbean (FAO-SLC), Barbados. http://j.mp/1aGV7Aj

[18] Perez-Vicente, L. (2013) Manual on Fungicides and fungicide Resistance Monitoring in Banana. Food and Agriculture Organization of the United Nations, Subregional Office for the Caribbean (FAO-SLC), Barbados. http://j.mp/132tj7Y

[19] Tushemereirwe, W., Batte, M., Nyine, M., Tumuhimbise, R., Barekye, A., Tendo, S., Talengera, D., Kubiriba, J., Lorenzen, J., Swennen, R. and Uwimana, B. (2015) Performance of NARITA Banana Hybrids in the Preliminary Yield Trial for Three Cycles in Uganda. IITA, NARO, Uganda, 35.

http://www.iita.org/c/document_library

[20] Sharm, H.C. and Ortiz, R. (2002) Host Plant Resistance to Insects: An Eco-Friendly Approach for Pest Management and Environment Conservation. Journal of Environmental Biology, 23, 111-35.

[21] Tumuhimbise, R., Barekye, A., Kubiriba, J., Tushemereirwe, W.K., Akankwasa, K., Arinaitwe, I.A., Karamura, D. and Tushemereirwe, W.K. (2018) New High-Yielding Cooking Banana Cultivars with Multiple Resistances to Pests and Diseases ("NAROBan1", "NAROBan2", "NAROBan3" and "NAROBan4") Released in Uganda. HortScience, 53, 1387-1389. https://doi.org/10.21273/HORTSCI13207-18

[22] Tumuhimbise, R., Buregyeya, H., Kubiriba, J., Tushemereirwe, W.K., Barekye, A., Tendo, R.S., Namagembe, B., Muhangi, S., Kazigye, F., Talengera, D., Tindamanyire, J. and Akankwasa K. (2019) "NABIO808” (Syn. "NAROBAN5"): A Tasty Cooking Banana Cultivar with Resistance to Pests and Diseases. Crop Breeding and Applied Biotechnology, 19, 502-506. https://doi.org/10.1590/1984-70332019v19n4c71

[23] Akankwasa, K., Ortmann, G.F., Wale, E. and Tushemereirwe, W.K. (2013) Farmers' Choice among Recently Developed Hybrid Banana Varieties in Uganda: A Multinomial Logit Analysis. Agrekon, 52, 25-51.

https://doi.org/10.1080/03031853.2013.798063

[24] Tushemereirwe, W.K., Nankinga, C., Kashaijja, I. and Tinzaara, W. (2003) Banana Production Manual Fountain Publishers. 2nd Edition, National Agricultural Research Organization, Kampala, Uganda.

[25] Ortiz, R., Vuylsteke, D., Ferris, R.S.B., Okoro, J.U., N'Guessan, A., Hemeng, O.B., Yeboah, D.K., Afreh-Nuamah, K., Ahiekpor, E.K.S., Fouré, E., Adelaja, B.A., Ayodele, M., Arene, O.B., Ikiediugwu, F.E.O., Agbor, A.N., Nwogu, A.N., Okoro, E., Kayode, G., Ipinmoye, I.K., Akele, S. and Lawrence, A. (1997) Developing New Plantain Cultivars for Africa. Plant Varieties and Seeds, 10, 39-57.

[26] Carlier, J., De Waele, D. and Escalant, J.V. (2003) Global Evaluation of Musa Germplasm for Resistance to Fusarium Wilt, Mycosphaeralla Leaf Spot Diseases and Nematodes. In: Vezina, A. and Picq, C., Eds., Performance Evaluation, Montpellier, France, 
57.

[27] Payne, R.W., Harding, S.A., Murray, D.A., Soutar, D.M., Baird, D.B., Glaser, A.I., Welham, S.J., Gilmour, A.R., Thompson, R. and Webster, R. (2011) The Guide to GenStat Release 14, Part 2: Statistics. VSN International, Hemel Hempstead (UK).

[28] Microsoft EXCEL (2016) Learn Excel Basics with Quick Examples. https://wp/excel-basics/

[29] Wortmann, C.S. and Eledu, C.S. (1999) Uganda's Agroecological Zones: A Guide for Planners and Policy Makers. Vol. 3, Centro Internacional de Agricultura Tropical (CIAT), Kampala, Uganda, 55.

[30] Robinson, J.C. and Alberts, A.J. (1986) Growth and Yield Responses of Banana (Cultivar Williams') to Drip Irrigation under Drought and Normal Rainfall Conditions in the Subtropics. Scientia Hort, 30, 187-202. https://doi.org/10.1016/0304-4238(86)90097-X

[31] Tushemereirwe, W. (1996) Factors Influencing the Expression of Leaf Spot Diseases of Highland Bananas in Uganda. Ph.D. Thesis, University of Reading, UK.

[32] Orjeda, G. (1998) Evaluation of Musa Germplasm for Resistance to Sigatoka Diseases and Fusarium Wilt. INIBAP Technical Guidelines, 3. International Plant Genetic Resources Institute, Rome, Italy; International Network for the Improvement of Banana and Plantain, Montpellier, France; ACP-EU Technical Centre for Agricultural and Rural Cooperation, Wageningen, The Netherlands.

[33] Vuylsteke, D., Swennen, R. and Ortiz, R. (1993) Development and Performance of Black Sigatoka Resistant Tetraploid Hybrids of Plantain (Musa spp, AAB Group). Euphytica, 65, 33-42. https://doi.org/10.1007/BF00022197

[34] Kagezi, G., Mpiira, S., Jogo, W., Karamura, E., Gotor, E., Garming, H. and Johnson, V. (2012) Adoption of New Banana Varieties in Uganda Report for the DIIVA Project. Bioversity International, Rome. 